UDK 01.001

\title{
Bibliografinè apskaita: ar paplitęs mokymas vis dar tinkamas
}

\section{Retha SNYMAN}

Pretorijos universiteto Informacijos mokslo fakultetas. Piety Afrikos Respublika,

el. paštas: msnyman@postino.up.ac.za

Ivadas

Noredamas pavaizduoti duomen Loras (1996) metaforiškai palygino ji su žvejybos tinklu arba tinkleliu petcliškèms gaudyti. Jis piešia bibliognfine apskaita kaip kuo tankiausią bibliografijos priemoniy ir bibliografiniu duomenu bazin tinte pro burio snulkinusiss akutes negalcul prosprüsti jols leidinys, hou jis püreger jis cricinames

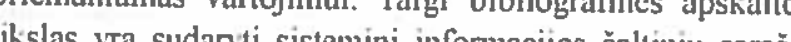
eiď̆ yun žn

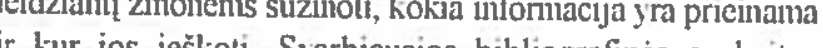
ilitos veiklos sritys apima informacijos šaltimi isigijima, ju bibliograffini aprasu sudaryma, bibliografinès paieškos pradmenç (1 kuri feina Kasifhavimas, zodiniu dalykiniy rubrik nustatymas, indeksavimas, referavimas) ir autoritetini

Šio straipsnio tikslas - aptarti bibliografines apskaitos mokymo motyvus, pristatyti naujus pasiekimus lendencijas, kurios galèty paveikti bibliografines apskaito mokymį nustatyt, kokic turêtu bũtí bibliografo sugebèjimai, pasiūlyti mokymo programą is užsiènimu plana

Bibliografinès apskaitos mokymas

Valstybinè ir visuotinè bibliografinè apskaita

Bibliografinè apskaita valstybiniu lygmeniu pateikia sistema. igalinančiią identifikuoti ir lokalizuoti informacijos šaltinius toje šalyje. Be fiziniu vienetu burie sulurian šalyje, identifilavimo, flērimo, surintimo ir sougojimo, labai svarbus yr bibliogrefini inšs lurie aprošo

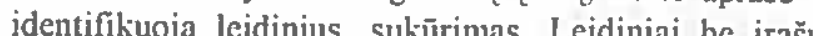

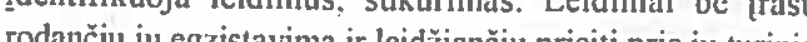
ro

Žyelgint $i$ valstybinés bibliogn

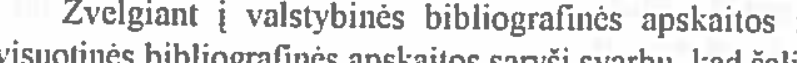
visuotines bibliografines apskatlos saryšl svarbu, kad šal būtu atsakingos už autoritetiniu ir bibliografiniu irašı sudarynı̨ kiekvienam naujam leidiniui, išlcistam laikantis priinty tarptautinin standartu Jcigu visos vals

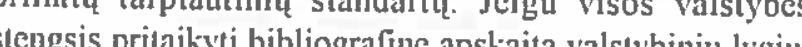
visuotine bibligrano imanoma.

Biblioteky ir informacijos tarnyby

bendradarbiavimas

Bibliotekos ir informacijos tarnybos dè finansiniu apribojintu ir išleidžianny informacijos šaltinin gausos jau phoju ir saus jau isist insilu podel šios ir dajo kopo

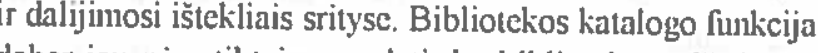
dabar jau nèra tiktai „parodyti, ką bibliotcka turi“, bet ir parodyth, ka bibliotcka gali isigyti ir patcikti skaitytojui. Todel bibliotckos sukurti katalogo jrašai turi tikti ir platesniam vartojinui.

Kokybiškas skaitytoju aplarnavimas

Mūsu laikais išskirtinis dèmesys skiriamas okybiškam aprūpinimui produktais ir kokybiškia aptarnavinuui. Daniel $(1993,46)$ Leigia, kad „informacijos pecialistai turètu prisiimti didesnę atsakomybe už eikiamy produkt! if klient! aplarnavino kokybe" Lozano (1997:148) žcngia toliau. sakydamas ,kokybés negalima suvesti tik i „tai, kas siüloma“" (turima onenyjc kokybiškas produktas arba aptarnavimas) - yra svarb kaip tai pasiüloma“.

Bibliotekinis arba informacinis aptarnavimas pramonés šaka kaip ir kitos. Šiı paslaugu klientai ir tiesioginiai vartotojai puikiai supranta apie kokybe Aišku kad ta bibliotcka, kuri ignonoja bibliografue apsain visiškai netinkamai, neišsamiai panaudoja savo fondus ir ikrai neteikia vartotojui paslaugu, kuriu jis veras. Bibliografiné apskaita iš esmés yra kolybès garan Corma. Ji gali būti traktuojama kaip priemone kura pagristas katalogas, arba duomen baze, wrikina vartotojo ir informacijos squveikos kobybe.

\section{Sistemy ir duomeny baziu raida}

Šiandiena galingais kompiuteriais galima atlikti sudètingas paicškas. pavyzdžiui, taikant Būlio logiką arba atmetino taisykleç. Tačiau vidinè tiesioginio ryšio sistemy architektüra remiasi projektais, kuriuos teikia bibliografine apskaita (Gomuan. 1992:694). Vystantis duomenu bazéms ir tiesioginio ryšsio sistemonns, vertinga ivesti gali patcikti tik žmonès, ǐšaniai susipažinę su bibliografinès apskaitos principais.

Todèl visiškai aišku, kad bibliografinı̀'s apskailos mokymas išliks būtlinybe, norint užtikrinti valstybinç ir visuotinę bibliografinç apskaita. igalinančia infornacijos tarnybas dalintis ištckliais ir katalogo irašais, tcikti kokybiškas paslaugas varıotojui ir plètoti efektyvias tiesioginio ryšio sistemas.

Šiuolaikinès tendencijos, galinčios daryt jtaką bibliografinés apskaitos mokymui

Procesu kompiuterizavimas

Akivaizdžiausias ir galbūt svarbiausias socialinis reiškinys, darantis itaka bibliografinci apskaitai, yra bibliotekiniu procesy kompiuterizavimas ir teclnologiniai pokyčiai. Bütina ne tik mokéti katalogavimo taisykles ir

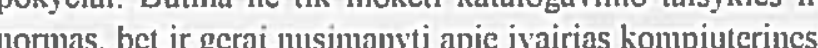
sistemas, programines irangas, tiesioginio ryšio bibliografinius tinklus.

Tinklo sukūrimas ir vidinė jungtis

Bibliografiniai tinklai ir konsorciumai dabar yra jprasta bibliografijos peizažo dalis. Atsiradus bibliografinianıs tinklams ir konsorciumams, padidèjo bibliografinès apskaitos poreikis. Anksčiau kickviena biblioteka galèjo taikyti savoms kartotckoms savus standartus, o bibliografiniai tinklai ir konsorciumai nelcidžia šios ivairovès bei prabangos, rcikalauja išsamiu ir standarttzuotụ bibliografiniu irašu.

Internelas

Intemetas sukèlè miľ̌̉iniški susidonçjimą. Vartotojai naršo po bibliografini kosmosa tikédamicsi surasi naudingos informacijos. Tačiau paieškos sistemos nèra linkamos priemonès informacijai gauti. nes paaiškèjo. kad „nei visateksčio, nei reikšminio žoď̌zio paicška nepasirodè geras pakaitalas struktūriniu irašu lauku paieškai vykdyti ir jokia rodyklè nepakcitè katalogo
surogatinuy irašu architektǚros" (Dillon ir Jul, 1996:216).

Bibliockos tip pat suproto kad apribodamos savo

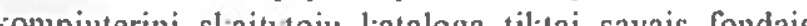

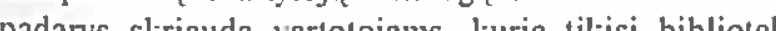

kataloge rasti gausios informacijos. Todèl daug tiesioginio ryšio katalogu buvo praplésti sickiant itraukti interneto saltininis. Irašu, aprašančił interneto ištcklius, integravimui reikia dideliu pastangu, norint pasiekti, kad metaduomenys pirminiuose dokumentuose atitiktų standartus, reikalingus integruoti šiuos pirminius šaltinius i cgzistuojančias informacijos perdavimo sistemas (McDomnell, Koeller ir Carroll. 1999:39)

Bibliografinès apskaitos naujovés

Su bibliografinc apskaita susijusios problemos, ypač tarplautinio lygio. ir kompiuteriniu lechnologiju galimybès iškèlè nauju idèjut, pavyzdžizi, sukurti vardo numeri ir .Dublin Core" metaduomeny elementy rinkini.

Praktinis mokymas

Darbe igyjama praktika ir patirtis visada buvo laikoma katalogavimo patirties, studentai turi kelet̨a savaičiu dirbli gamybojc. Dèl riboto biblioteku ir informacijos tanıbbu personalo darosi vis sunkiau dalyvauti tokiose programose, bendradarbiaujant su švictimo ir mokymo institucijonis.

Šios pripažintos tendencijos daro akivaizdu poveikł bibliorrates apstaitos studijoms ir laukianiens studentu darbo rezultans. Iš bibliogro tikimi dre tures ir naujy zinlin bei patirtics. Spaudima jaučia ne tik studentai, bet ir ǔ̆ ju
rengima atsakingi asmentys.

Bibliografinei kompetencijai igyti reikalingos savybès

Atsižvclgiant $i$ dabartini darbo turini ir naujus pasickinus, galima kelti klausima: kokias kompetencijos sritis bibliografas privalo ivvaldyti, kad galèty vykdyti uždavinius, apic kuriuos kalbèta anksčiau? Visiškai aišku, kad bibliografinei apskailai reikia tan tikry priemoniu detaliu žiniu. kaip valdyti šias priemones, ir praktiniu igūdžiu. norint gerai atlikti savo darba.

Bibliografines apskaitos pricmonès yra:

. Bibliografijos standartai ir taisykles

Bibliografas turi žinoti ir mokéti pritaikỵ bibliografinius slandartus kurdamas tick metaduomenis tiek bibliografinius duomenis

II. Aplinka

,Joks žmogus uèra sala” ir „dvi galvos geriau negu viena" kalba už save.

III. Intelckias

Bibliografas turi mokèti mąstyti analitiškai. sistemiškai ir kritiškai, kad galétı, pavyzdžiui, išanalizuot leidinio turing ir nustalyti teisinga dalykine rubrika arba klasiffkacijos indeksq. 
IV. Kompiuteris

Sis irankis padeda atlikti veiksmus ir igvvendinti idéjas. sukurtas I. II ir III priemoniu sqqueikos.

Bibliografai privalo jvaldyti visas keturias priemones, kad jụ darbas būtu kokybiškas. Kad galc̀tıl tai padaryti, privalo turèti šiuos igũdžius:

Katalogavimo ir sisteminimo jgūdžiai

Nors kai kurie tradiciniai bibliotckininai ıgūdžiai, kaip raš̌ Išdéstymo tvarka ir rüšiavimas, darosi vis mažiau svarbüs kompiuterinèse duomen! bazėse, tokios veiklos sisteminimas ir autoritetinc apskaita ir toliau lhs pagnindhiai procesai, nepriklausoma nuo to. ar rengiani spausdinti, ar elektroniniai išteklia

\section{Analitinio ir krilinio mąstymo igūdžiai}

Analitinio ir kritinio mąstymo igūdžiai lemia profesin scekmę daugclyje sričiu. Šic igūdžiai bus rcikalingi, norin perprasti daugeli lurinıo rũšių ir naujus elektroniniı formalus, kuric lampa pricinami.

\section{Mokèjimas dirbti kompiuteriu}

Dèl nauju teclnologiju ir nauju lcidiniu rūši nformacijos profesionalanıs išskilo būtinybe išmok kvalifikuotai valdyti ir vartoti informacijos apdorojimu paicškai ir perdavimui moderniausias tecluılogijas be sąsajas.

Taigi galima padaryti išvadq, kad, be tradiciniu darb gundžiul: katalogavimo ir sisteminimo, bibliograłas privalo mokèti dirbti kompiuteriu, kad galèty neatsilikti nu bibliografines apskaitos progreso.

Tarpusavio bendradarbiavimo igūdżiai

Reikia išsiugdyti tvirtus bendradarbiavino igūdžius Bibliografai nedirba vicnumoje - dažniausiai jic glaudžia bendradarbiauja su kolegomis, pataria vienas kitam, reguliariai aptaria darbo klausimus.

Bibliografinès apskaitos mokymo programa ir procesas

Pastaruoju metu buvo daug rašyta apic kompetentingu bibliografu stokos pricżastis. Bibliotekininkystes mokyklonls prickaistaujama, kad neparengia pakankamai gern kataloguotoju. Buvo taip pat kritikuojamas bibliografinès apskaitos kursas. Šta dalis kritiniu pastabu

bibliolchininkysles mokyklos išlcidžia studentus ne visiškai parengtus darbui, kuri jie turi daryti;

- studentai suvokia katalogavimo kursq kaip keista ir dažnai penıelyg komplikuota:

netodai, pagal kuriuos mokoma katalogavimo, neatitinka praktiskai alliekano darbo:

mokymo programoje neatsispindi nauji katalogavimo srities pasickimai

- déstytojai nèra pakankamai kompetentingi perteikti studentams informacijos teclunologiju naujoves:

katalogavimo mokymui skirtas laikas vis labiau trumpinamas kity tenul labuif:

mażaar mokoma bibliografines apskaitos teorijos: nepakanka prakitikos darbıl. kuriy metu studentai galètu gerai îtvirtinti teorines žinias:

- nuobodũs mokymai klasésc.

Nors matome daug kritikos, tačiau sulaukiame mažă pasiūlymul, kaip pagerinti šio kurso kohybc. Atsižvelgiant naujas kryptis ir rciškianı kritika yra aišku kad

- reikalingas tinkamas tcorinis pagrindas:

- teorija ir praktika turi būti gerai subalansuotos:

- mokirmo procese turctu alsispindèti ahtualios 1.t.;

- studentai turi bũti mokomi savarankiškiai vertinti. krițškai ir analitiškai mąsıłtiti

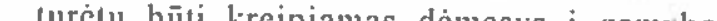
progresa. nes sludentus reikia rengi progresal,

- reikia atrasti naujı. jdomiy mokymo melodu:

destytojo vaidmuo is ", "nledžiagos pertecikéjo" tur keistis $i$, ,interakityvy vadova”, o studento - is̆ "informacijos sugerejo" i ,interaktyvu dalyvi". Literatūroje pabrèztinai akcentuojamas kurso turiulys. bet ne mokymo metodika. Gonmano straipsnyje (1992 694) pateikiama geriau subalansuota mokomojo dalyko programa, kuri galètu būti pagrindas ir sulciktı galimybes studentans daug efektyviau veikti esant tivairiom situacijoms. Tačiau programoje skina nedaug laiko moky bibliografines apskailos principl ir veiklos, lodél studenta negali gerai plvaldyti reikalingu igưưž̀ı. Dél laiko stoko kursuose nę̧manoma ismokli ko nors daugiau neg bibliografines apskailos principy ir veiklos pagrind Zzdavinys aleičiai - išmokyti studentus mastyti ir priim sprendinuss, o ne vien supažindinti su priemonemis ecluikia.

Kaip jau buvo minèta, praktinis darbas yra sudétine katalogavimo kurso dalis. Tačiaut bibliotekons darosi vis sunkiau dalyvauti mokymo programose. Kita vertus. studentai turi turèti galinutbe spresti realius ǚdnvinis realiomis salygonis. To galima pasickti modeliavim grupiniu darbu ir seminarais Dar daugian, reike panaudoti golimybes, lurias siño su pikin technologijos. Mokymo prograns gale büt patines per żiniasklaidos ir technologijos derini (spalding tekstai, CD-ROM, wwe, elehtronins grupes, kompiuterizuolas mokymas). Unikalios www savybes ir didžnults tunklapiny su informacijos saltinjais skaičius yra kintanimiẹı dydžıai patraukliame pasaulyje. kuriame plétojasi moks̀mo ir mokymosi patirties ivairove.

Išvados

Visiškai aišku. kad bibliografinè apskaita bus reikalinga nuolat ir studentus reikès rengti šiam darbui.

Daniel, E.H. 1993. Quality control of documents. Librury trends.

Dillon, M. \& Jul, E. 1996. Cataloging Internet resoures: the convergence of libraries and Internet resources. (In: Pattic, L.E. \& Cox, B J., ed. Electronic resontress: selection and hithliographitic

Gornan, M. 1992. How cataloguing and classilication should be

Lor, P.J., 1996. Bibliographlic standards in context: cutrent chal-
Nauji metodai ir teclinika vers déstytojus tapti kur kas labiau novatoriskus. Tai. mano muomone. yra bülina salyga, kad studenty rengimas buitly velksmingesnis. kad studentai igytu kompetenciją. reikalinga gamybinians poreikiams patenkinti. Mes. kaip mokytojai ir vadovai, turime priimti și iššñiki.

Iš anglu $k$. verte $A$. Staskevičius

cenges in bibliographic control (in: Coetzece, H.S. ed. Seminar on Bibliograptic Stamdards for the Promotion of Co-operation. Pretonia, 1-2 Sebriand Pretora Universily of Pretoria: 1-23). (a) McDonncll. J.P. Kockller, W. C., J. \& Carroll, B.C. 1999 . Cataloging ellallienges in an Area Studies Virtual Library Catalog (ASVLC): results of a case study. Journal of linternet catalognt- 